\title{
Comment on "The Changes of Blood Glucose Control and Lipid Profiles after Short-Term Smoking Cessation in Healthy Males"
}

\author{
Tomoyuki Kawada \\ Department of Hygiene and Public Health, Nippon Medical School, Tokyo, Japan
}

Sir,

Lee et al. ${ }^{1}$ reported the interesting finding that smoking cessation in healthy males was associated with a significant increase of insulin resistance, and speculated that the increase of the body weight following smoking cessation might contribute to the worsening of insulin resistance. They dealt with a small number of subjects and the follow-up period was only 2-months. As opposite results, they cited one report of increase of insulin resistance in 63 normoglycaemic smokers as compared to 21 non-smokers and 35 former smokers with normoglycaemia. ${ }^{2}$ Cena et al. ${ }^{3}$ suggest that nicotine, carbon monoxide, and other metabolites derived from nicotine may play important roles in insulin resistance. On this point, Eliasson et al. ${ }^{4}$ reported that the degree of insulin sensitivity was negatively correlated with the extent of nicotine use, as measured by the plasma cotinine level, in long-trem nicotine gum users $(\mathrm{n}=20, \mathrm{r}=-0.469, \mathrm{p}=0.034)$. In order to $\mathrm{cl}-$ arify these associations, the salivary cotinine and nicotine concentrations of 180 male smokers were measured.

The mean age \pm standard deviation (range) of the subjects was $42.8 \pm 6.2$ (33-58). Subjects at a workplace with a current history of treatment for diabetes and/or subjects whose fasting plasma glucose level was $\geq 140 \mathrm{mg} / \mathrm{dL}$ were excluded from the analysis. Sampling of saliva was conducted using Salisoft ${ }^{\circledR}$ (Assist Co. Ltd., Tokyo). The analyses were performed by highperformance liquid chromatography using "CAPCELL PAK MG II C18” (Shiseido Co. Ltd., Tokyo) columns under the

Received: March 22, 2012 Revised: April 9, 2012

Accepted: April 9, 2012 Available online: May 10, 2012

$\triangle$ Correspondence: Tomoyuki Kawada, MD

Department of Hygiene and Public Health, Nippon Medical School, 1-1-5 Sendagi, Bunkyo-Ku, Tokyo 113-8602, Japan

Tel: +81-3-3822-2131, Fax: +81-3-5685-3065, E-mail: kawada@nms.ac.jp

(a) This is an Open Access article distributed under the terms of the Creative Commons Attribution Non-Commercial License (http://creativecommons.org/licenses/by$\mathrm{nc} / 3.0$ ) which permits unrestricted non-commercial use, distribution, and reproduction in any medium, provided the original work is properly cited. temperature of $50^{\circ} \mathrm{C}$ and wavelength of $262 \mathrm{~nm}$. The detection limits for nicotine and cotinine were $5 \mathrm{ng} / \mathrm{mL}$ and $10 \mathrm{ng} /$ $\mathrm{mL}$, respectively. As an indicator of insulin resistance, the homeostasis model assessment for insulin resistance (HOMA$\mathrm{IR})^{5}$ was calculated as follows: HOMA-IR $=$ (Fasting plasma glucosexFasting serum insulin)/405. Units of glucose and insulin used for the calculation of HOMA-R were $\mathrm{mg} / \mathrm{dL}$ and $\mu \mathrm{IU} / \mathrm{mL}$, respectively. Bernert et al. ${ }^{6}$ reported a regression line of salivary cotinine against the serum cotinine as $\log _{10}$ (salivary cotinine $)=0.963 \times \log _{10}$ (serum cotinine $)+0.127$, with the square value of the correlation coefficient of 0.997.

The main finding was that the log-transformed salivary cotinine and log-transformed salivary nicotine concentrations had no significant relationship with the log-transformed HOMA-IR. The partial correlation coefficients after adjustments for the age and body mass index were -0.056 for salivary cotinine and -0.047 for salivary nicotine, respectively. Thus, it was found using biological indicators of tobacco use, that the relationship between smoking and insulin resistance was weak after adjustment for age and body mass index. Although HOMA-IR is only a substitute indicator of insulin resistance ideally determined by the glucose clamp method, which was adopted by Eliasson et al. ${ }^{4}$ it is a simple and reliable method to detect insulin resistance in subjects without insulin depletion or insulin treatment.

Numerous factors can affect insulin resistance, and I recommend that the net effect of smoking on insulin resistance should be examined in further detail.

\section{REFERENCES}

1. Lee SS, Seo JS, Kim SR, Jeong JE, Nam BW, Lee JY, et al. The changes of blood glucose control and lipid profiles after short-term smoking cessation in healthy males. Psychiatry Investig 2011;8:149-154.

2. Daniel M, Cargo MD. Association between smoking, insulin resistance and beta-cell function in a North-western First Nation. Diabet Med 2004;21:188-193. 
3. Cena H, Fonte ML, Turconi G. Relationship between smoking and metabolic syndrome. Nutr Rev 2011;69:745-753.

4. Eliasson B, Taskinen MR, Smith U. Long-term use of nicotine gum is associated with hyperinsulinemia and insulin resistance. Circulation 1996;94:878-881.

5. Matthews DR, Hosker JP, Rudenski AS, Naylor BA, Treacher DF, Turner RC. Homeostasis model assessment: insulin resistance and b- cell function from fasting plasma glucose and insulin concentrations in man. Diabetologia 1985;28:412-419.

6. Bernert JT Jr, McGuffey JE, Morrison MA, Pirkle JL. Comparison of serum and salivary cotinine measurements by a sensitive high-performance liquid chromatography-tandem mass spectrometry method as an indicator of exposure to tobacco smoke among smokers and nonsmokers. J Anal Toxicol 2000;24:333-339. 